Brazilian Journal

of Chemical

Engineering

\title{
Mentha arvensis IN OIL SOLID-LIQUID EQUILIBRIUM
}

\author{
Aline A. O. Alves ${ }^{1,2^{*}}$, Wagner Aldeia ${ }^{1}$, Guilherme C. Ungar ${ }^{1}$ and Silas Derenzo ${ }^{1}$ \\ ${ }^{1}$ Instituto de Pesquisas Tecnológicas, São Paulo, SP, Brasil. E-mail: aline.araujo.oliveir@gmail.com, ORCID: 0000-0002-6787-0735; \\ ORCID: 0000-0002-9914-819X; ORCID: 0000-0002-0850-3900; ORCID: 0000-0001-8803-6961 \\ ${ }^{2}$ Yah Sheng Chong Comércio e Indústria Ltda, Diadema, SP, Brasil.
}

(Submitted: November 13, 2017 ; Revised: April 12, 2018 ; Accepted: August 31, 2018)

\begin{abstract}
L-menthol is an essential oil produced from Mentha arvensis. An experimental L-menthol solidliquid equilibrium in menthol oil constituents was determined in the temperature range between $271 \mathrm{~K}$ and $300 \mathrm{~K}$, by the method of creating a saturated solution at a given temperature by using an excess of crystals in the suspension. The mole fraction of the experimental data, on a logarithmic basis, were fitted against $\mathrm{T}$ by the Apelblat equation and by a linear equation with good results. The equations were: $\ln (\mathrm{x})=[-52.45+1,170.70 / \mathrm{T}$ $+8.48 . \ln (\mathrm{T})]$ and $\ln (\mathrm{x})=3.98-1,249.65 / \mathrm{T}$ with $\mathrm{T}$ in $\mathrm{K}$. Both equations give a good correlation with the experimental data. From the Apelblat equation the enthalpy of solution was also calculated as a linear function of temperature and has an average value of $150.31 \mathrm{~J} / \mathrm{mol}$ in the temperature interval studied.

Keywords: Solubility; Phase equilibria; L-Menthol.
\end{abstract}

\section{INTRODUCTION}

L-menthol is a widely used compound in the food, cosmetic and pharmaceutical industries (Gupta et al., 2017; Watts, 1997; Budavari, 1989), where it is mainly applied as solid crystals. It is the main constituent of peppermint oils from Mentha arvensis (content: 70 to $80 \%$ ) and Mentha piperita (content: 50 to $60 \%$ ) (Nowak et al, 2013,). Most recently, Tardugno et al (2017) compared the composition of these two mentha species and reported that the L-menthol percentage in M. arvensis is twice as high as in M. piperita.

The extraction of the oil is typically carried out by steam stripping, with yields around $1 \%$ to $5 \%$, depending on the mint species used. After heating, filtering and dewatering steps, the extracted oil is cooled to temperatures between $-5{ }^{\circ} \mathrm{C}$ and $-10{ }^{\circ} \mathrm{C}$. At this temperature menthol powder precipitates from the oil. The dementholized mint oil (DMO), is then cooled to $-40{ }^{\circ} \mathrm{C}$, precipitating another quantity of menthol powder. (Watts, 1997). For decades nearly all menthol crystal industries have been performing the crystallization process by subjecting the mint essential oil to temperature programmed procedures established empirically or following patented cooling schemes (Bridger and Chang, 1953; Watts, 1997; Gatfield et al., 2004). Some of these crystallization processes may take thirty days, with final temperatures around -30 ${ }^{\circ} \mathrm{C}$. More recent processes may require less time, such as the one described by (Nadeem et al., 2017), which take 48 hours at $-45^{\circ} \mathrm{C}$.

Because of these long batch processing times, the energy consumption is too high. Also, there is little control over the crystal size distribution (CSD) due to the occurrence of crystal nucleation and seed growth phenomena simultaneously. Therefore, the need for improvements to the traditional crystallization process is clear.

Besides the mint species, the oil composition also depends on the harvest place and period (Watts, 1997) and comprises dozens of components such as monoterpenes, sesquiterpenes, oxidized terpenes and so on (Hussain et al., 2010). Most of the existing literature presents just the major constituents of the

\footnotetext{
* Corresponding authors: Aline A. O. Alves - E-mail: aline.araujo.oliveir@gmail.com
} 
oil (essentially menthol, menthone, menthyl acetate, limonene and isomenthone), accounting for $80 \% \mathrm{wt}$ to 98\%wt of its composition (Singh et al., 2005; Hussain et al., 2010; Gupta et al., 2017).

Becker et al. (1978) pointed out that, despite its abundance, there are little information available on menthol's thermophysical properties. Galushko et al. (2006) compiled some physicochemical properties of menthol, namely molecular weight (156.27), melting temperature $\left(43.5^{\circ} \mathrm{C}\right.$ ) and heat of fusion $(78 \mathrm{~J} / \mathrm{g})$. Menthol's boiling point $\left(21{ }^{\circ} \mathrm{C}\right)$ may be found on Budavari (1989). Due to the interest in supercritical extraction, some authors (Sovová and Jez, 1994, Mukhopadhyay and De, 1995, Galushko et al., 2006) present the solubility of the mint essential oil in supercritical $\mathrm{CO}_{2}$. Also, Okuniewski et al. (2017) obtained the menthol solubility in n-dodecane, 1-dodecanol, and 2-phenylethanol, but no information was found about the solubility in DMO, object of this paper.

\section{Thermodynamic model}

Solid-Liquid Equilibrium (SLE) may be represented thermodynamically by the van't Hoff equation for ideal systems (Mullin, 2001; Myerson, 2002; Sandler, 2017):

$$
\ln \left(\mathrm{x}_{\text {ideal }}\right)=\frac{\Delta \mathrm{H}_{\text {fusion }}}{\mathrm{R}}\left[\frac{1}{\mathrm{~T}}-\frac{1}{\mathrm{~T}_{\text {melt }}}\right]
$$

where $\mathrm{x}_{\text {ideal }}$ is the ideal saturation mole fraction of the solute, $\mathrm{R}$ is the ideal gas constant, $\mathrm{T}$ is the temperature of the system, $\mathrm{T}_{\text {melt }}$ the fusion temperature, $\Delta \mathrm{H}_{\text {fusion }}$ the molar heat of fusion and $\gamma$ the activity coefficient.

According to thermodynamics, the hypothetical path is to heat the solid from $\mathrm{T}$ to $\mathrm{T}_{\text {melt }}$, change phase from solid to liquid at that temperature and cool the liquid phase back to T. This implies some assumptions: there is no interaction between solute and solvent (Mullin, 2001), the equation would serve for any solvent and there are no data correlating the specific heat to cool the liquid phase. Some approximations, according to Mishra and Yalkolwsky (1992) caused until 12\% difference of solubility.

For real solutions, a better approach for a binary or multicomponent system is to adjust the equation to replace the heat of fusion by the heat of solution (Nývlt et al., 2001) to consider solvent -solute interactions:

$$
\frac{\mathrm{d} \ln \left(\gamma \cdot \mathrm{x}_{\text {ideal }}\right)}{\mathrm{dT}}=\frac{\mathrm{d} \ln (\mathrm{x})}{\mathrm{dT}}=\frac{\Delta \mathrm{H}_{\text {sol }}}{\mathrm{RT}^{2}}
$$

where $x$ is the mol fraction of solid at equilibrium and $\gamma$ is the activity coefficient.
Considering that the heat of solution is a linear function of temperature:

$$
\Delta \mathrm{H}_{\mathrm{sol}}=\mathrm{a}+\mathrm{bT}
$$

Substituting (3) in (2) and integrating:

$\ln (\mathrm{x})=\mathrm{A}+\frac{\mathrm{B}}{\mathrm{T}}+\mathrm{C} \ln (\mathrm{T})$

where $\mathrm{A}$ is a constant of integration; $\mathrm{B}=-\mathrm{a} / \mathrm{R}$ and $\mathrm{C}$ $=\mathrm{b} / \mathrm{R}$.

This equation is traditionally used to adjust solidliquid equilibria (see, e.g., Noubigh and Oueslati, 2017; Bhesaniya and Baluja, 2014; Shi et al., 2016; Li et al., 2012; Baluja, 2012). Hence, the heat of solution can be calculated from the integration of Eq.4 to give Eq. 5:

$\Delta \mathrm{H}_{\mathrm{sol}}=-\mathrm{B} \cdot \mathrm{R}+\mathrm{C} \cdot \mathrm{R} \cdot \mathrm{T}$

If the heat of solution can be assumed to be constant in the temperature range, the integration of Eq. 2 yields:

$\ln (\mathrm{x})=\frac{\mathrm{D}-\mathrm{E}}{\mathrm{T}}$

where D is a integration constant, and the average heat of solution is $-\mathrm{E}$. R.

\section{EXPERIMENTAL SECTION}

The experimental set up consisted of a $150 \mathrm{~cm}^{3}$ jacketed glass reactor with a stirrer (Logen Scientific), a thermostatic bath (Fisatom, model 800) coupled and a digital thermometer (Gulterm model 1001, range: $-40{ }^{\circ} \mathrm{C}-199.9^{\circ} \mathrm{C}, \pm 0.1^{\circ} \mathrm{C}$ ). The mint oil (Refractive Index of 1.559 , Optical rotation of $-23^{\circ}$ ) contained around $48 \%$ of menthol (MW=156.26), $7 \%$ terpenes (limonene, myrcene and alpha and beta-pinene, all with $\mathrm{MW}=136.23), 37 \%$ of menthone, isomenthone and neoisopulegol $(\mathrm{MW}=154.25), 3 \%$ menthyl acetate $(\mathrm{MW}=198.31), 0.6 \%$ of piperitone $(\mathrm{MW}=152.23)$ and $0.4 \%$ of menthofuran $(\mathrm{MW}=150.22)$.

The adopted method is the excess time of liquid phase contact with an excess of crystals method (Myerson 2002) at a constant temperature. Based on previous research (Derenzo, 2003, Uematsu et al., 2006), the equilibrium normally is reached after 6 to 8 hours under stirring, but 24 hours was used in these experiments. 
An amount of $100 \mathrm{~cm}^{3}$ of this oil was kept in the reactor at a fixed temperature with an excess of menthol crystals for at least 24 hours under stirring. The stirring was stopped thereafter and kept standing for 10 minutes before a sample of the liquid phase was taken with the aid of a filter in a syringe. The sample was analyzed by gas chromatography as soon as possible to avoid sample crystallization. The assay was performed three times for each temperature in the range of 271 to $300 \mathrm{~K}$.

The chemical analysis were performed in a HP model 5890, Series II gas chromatograph, using a HP-20M column (Carbowax 20M - Polyethylene Glycol) with the dimensions of $50 \mathrm{~m} \times 0.2 \mathrm{~mm} \times$ $0.1 \mu \mathrm{m}$. The following operational conditions were applied: injection temperature of $250{ }^{\circ} \mathrm{C}$, column temperature of $110{ }^{\circ} \mathrm{C}$, FID temperature of $250^{\circ} \mathrm{C}$, synthetic air, nitrogen, oxygen and hydrogen as carrier gases. Concentration calculations were made using the N2000 Chromatography Data System software.

The equilibrium data were then fit by nonlinear regression method using MATLAB software with Levenberg-Marquardt nonlinear least squares algorithm, to estimate parameters A, B and D from the model shown by Eq. 4 and with the standard linear least squares algorithm to obtain the parameters from Eq. 6. Also, outlier analysis was performed after model fitting, by testing the residues (differences between calculated and experimental concentrations) for normality and using a 3-sigma criterion to eliminate experimental points which could prejudice the estimates. The quality of the model was assessed by the adjusted $\mathrm{R}^{2}$.

\section{RESULTS AND DISCUSSION.}

Table 1 presents the experimental data. Fitting of models from Equations 4 and 6 were performed and the results are presented in Figures 1 and 2, respectively.

The $\mathrm{A}, \mathrm{B}$ and $\mathrm{C}$ parameter estimates were, respectively: $-52.45 ; 1,170.70$ and 8.48 . Thus, the adjusted nonlinear model proposed for 1-menthol in the range of $271.15 \mathrm{~K}$ and $300.15 \mathrm{~K}$ is:

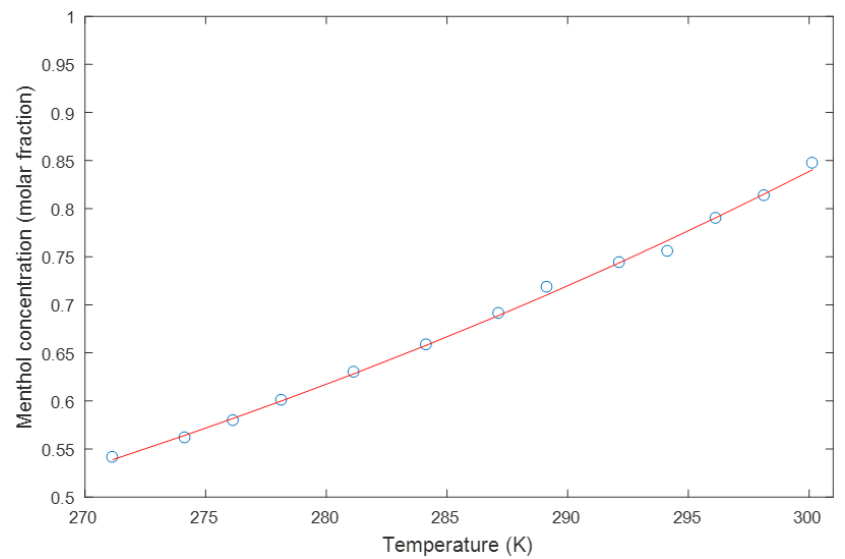

Figure 1. Graphical representation of the experimental and modeled l-menthol solid-liquid equilibrium curve by non-linear fitting.

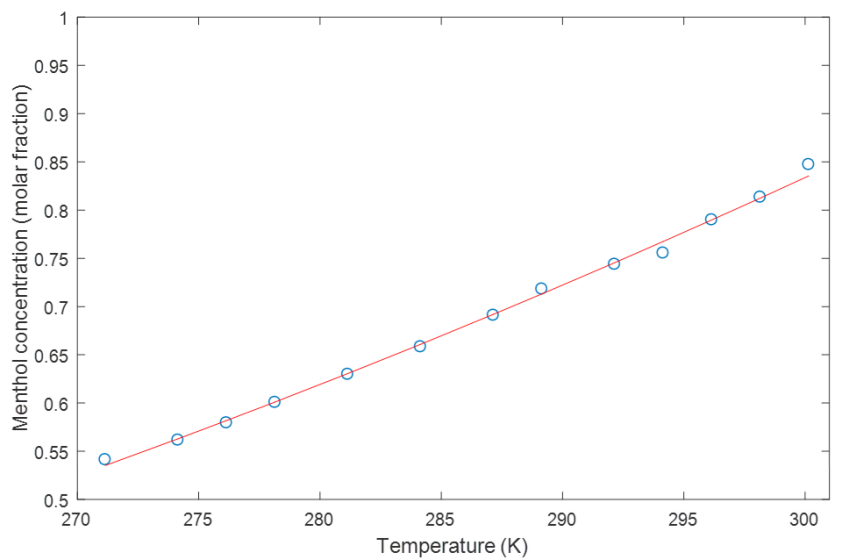

Figure 2. Graphical representation of the experimental and modeled 1-menthol solid-liquid equilibrium by linear fitting.

Table 1. Experimental saturation data of L-Menthol in the essential oil.

\begin{tabular}{|c|c|c|c|c|c|}
\hline \multirow{2}{*}{$\begin{array}{c}\text { Temperature } \\
\text { (K) }\end{array}$} & \multicolumn{3}{|c|}{$\begin{array}{l}\text { L-menthol experimental concentration } \\
\qquad(w t \%)\end{array}$} & \multirow{2}{*}{$\begin{array}{c}\begin{array}{c}\text { Average } \\
\text { concentration } \\
\text { (wt\%) }\end{array} \\
84.94 \pm 0.97\end{array}$} & \multirow{2}{*}{$\begin{array}{c}\begin{array}{c}\text { \%average } \\
\text { concentration } \\
\text { (mol\%) }\end{array} \\
84.71\end{array}$} \\
\hline & 85.83 & 83.91 & 85.07 & & \\
\hline 298.15 & 81.76 & 81.57 & 81.46 & $81.60 \pm 0.15$ & 81.33 \\
\hline 296.15 & 79.90 & 78.50 & 79.40 & $79.27 \pm 0.71$ & 78.98 \\
\hline 294.15 & 76.36 & 76.24 & 75.00 & $75.87 \pm 0.75$ & 75.54 \\
\hline 292.15 & 75.06 & 74.16 & 74.91 & $74.71 \pm 0.48$ & 74.37 \\
\hline 289.15 & 71.79 & 72.35 & 72.37 & $72.17 \pm 0.33$ & 71.81 \\
\hline 287.15 & 69.81 & 68.99 & 69.60 & $69.47 \pm 0.43$ & 69.09 \\
\hline 284.15 & 65.99 & 66.46 & 66.22 & $66.22 \pm 0.24$ & 65.82 \\
\hline 281.15 & 63.09 & 63.48 & 63.58 & $63.38 \pm 0.26$ & 62.97 \\
\hline 278.15 & 60.19 & 60.80 & 60.49 & $60.49 \pm 0.31$ & 60.06 \\
\hline 276.15 & 58.36 & 58.39 & 58.37 & $58.37 \pm 0.02$ & 57.94 \\
\hline 274.15 & 56.50 & 56.89 & 56.39 & $56.59 \pm 0.26$ & 56.15 \\
\hline 271.15 & 54.45 & 54.90 & 54.37 & $54.57 \pm 0.29$ & 54.13 \\
\hline
\end{tabular}


Table 2. Experimental and fitted menthol concentration according to equations 7 and 9 and heat of solution.

\begin{tabular}{|c|c|c|c|c|c|c|}
\hline $\begin{array}{c}\text { Temperature } \\
\text { (K) }\end{array}$ & $\begin{array}{c}\text { Concentration } \\
(\% \mathrm{~mol})\end{array}$ & $\begin{array}{c}\text { Concentration } \\
\text { according } \\
\text { to eq }(5) \\
(\% \mathrm{~mol})\end{array}$ & $\begin{array}{l}\text { Dev. } \\
\text { (\%) }\end{array}$ & $\begin{array}{c}\text { Heat of } \\
\text { solution }(\mathrm{J} / \mathrm{mol})\end{array}$ & $\begin{array}{c}\text { Concentration } \\
\text { according } \\
\text { to eq (7) } \\
(\% \mathrm{~mol})\end{array}$ & $\begin{array}{l}\text { Dev. } \\
(\%)\end{array}$ \\
\hline 300.15 & 84.71 & 83.75 & 1.13 & 165.34 & 83.24 & 1.73 \\
\hline 298.15 & 81.33 & 81.23 & 0.12 & 163.30 & 80.95 & 0.47 \\
\hline 296.15 & 78.98 & 78.79 & 0.24 & 161.26 & 78.69 & 0.36 \\
\hline 294.15 & 75.54 & 76.42 & 1.16 & 159.22 & 76.46 & 1.22 \\
\hline 292.15 & 74.37 & 74.11 & 0.35 & 157.18 & 74.27 & 0.13 \\
\hline 289.15 & 71.81 & 70.78 & 1.43 & 154.12 & 71.05 & 1.06 \\
\hline 287.15 & 69.09 & 68.65 & 0.64 & 152.08 & 68.94 & 0.22 \\
\hline 284.15 & 65.82 & 65.56 & 0.40 & 149.02 & 65.85 & 0.04 \\
\hline 281.15 & 62.97 & 62.61 & 0.57 & 145.96 & 62.83 & 0.22 \\
\hline 278.15 & 60.06 & 59.79 & 0.45 & 142.90 & 59.89 & 0.30 \\
\hline 276.15 & 57.94 & 57.98 & 0.08 & 140.86 & 57.97 & 0.06 \\
\hline 274.15 & 56.15 & 56.23 & 0.14 & 138.82 & 56.09 & 0.12 \\
\hline 271.15 & 54.13 & 53.70 & 0.80 & 135.76 & 53.33 & 1.48 \\
\hline $\mathrm{R}^{2}$ & 0.998 & & & 0.997 & & \\
\hline Average & & & 0.58 & 151.22 & & 0.57 \\
\hline Maximum & & & 1.43 & & & 1.73 \\
\hline
\end{tabular}

$\mathrm{dev}=\left(\mathrm{x}_{\exp }-\mathrm{x}_{\text {calc }}\right) / \mathrm{x}_{\exp }$

$\ln (x)=-52.45+\frac{1,170.70}{T}+8.48 \ln T$

and the heat of solution can be expressed as:

$$
\Delta \mathrm{H}_{\mathrm{sol}}=-140.81(\mathrm{~J} / \mathrm{mol})+1.02 \mathrm{~T}
$$

The constant heat of solution approach led to the following equation:

$$
\ln (x)=3.98-\frac{1,249.65}{T}
$$

The heat of solution calculated from this model was $150.31 \mathrm{~J} / \mathrm{mol}$, which is very close to the average value of the heat of solution from eq. 7 in the range studied: $151.22 \mathrm{~J} / \mathrm{mol}$, indicating that there is consistency of both fitted models.

Table 2 presents the calculated values of the heat of solution and the molar concentration for both equations. It can be seen that both equations properly fitted the experimental data, and the average deviation was similar for both models.

The adjusted $\mathrm{R}^{2}$ for these models were 0.998 and 0.997 respectively, indicating that both present good fit for the data set. After the model was built, the outlier analysis showed no residue outside the 3-sigma range. Figure 3 presents the residues plotted according to their respective saturation temperature, as well as the upper and lower limits calculated with the 3-sigma rule. As can be seen, although both equations may be accepted in this temperature range, the non-linear model has a lower deviation than the linear model.
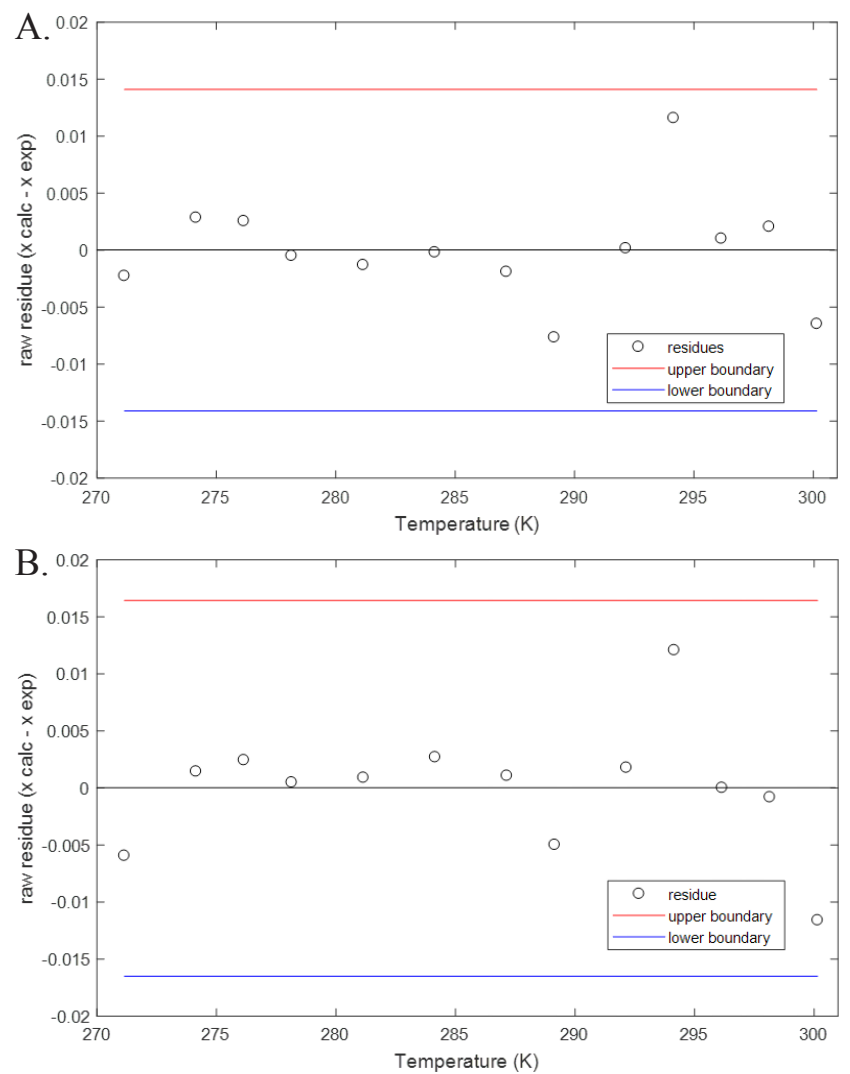

Figure 3. Residue distribution in (a) non-linear model and (b) linear model.

\section{CONCLUSION}

Based on experimental data it can be concluded that menthol solubility has a positive effect with the increase of temperature. Two mathematical models for L-menthol solid-liquid equilibrium were developed in the range of 271 to $300 \mathrm{~K}\left(-2{ }^{\circ} \mathrm{C}\right.$ to $\left.+27^{\circ} \mathrm{C}\right)$. The 
complete equation of the model is $\ln (x)=[-52.45+$ $1,170.70 / T+8.48 \cdot \ln (T)]$ and $\ln (x)=3.98-1,249.65 / T$ where $\mathrm{T}$ is the temperature in Kelvin and $\mathrm{x}$ is the mole fraction of L-menthol The heat of solution is a linear function of the temperature in the range assuming an average value of $150.31 \mathrm{~J} / \mathrm{mol}$.

\section{REFERENCES}

Baluja, S., Alnayab, E.A.M., and Hirapara, A., Thermodynamic Models for Determination of Solubility of Cellulose Acetate in Various Solvents at Different Temperatures. Acta Chim Pharm Indica, 7(4), 117, 1-12 (2017)

Becker, C., Reiss, H., and Heist, R.H., Estimation of thermophysical properties of a large polar molecule and application to homogeneous nucleation of $\mathrm{L}$ menthol. Journal of Chemical Physics, 68 (3), 3585 3594 (1978). https://doi.org/10.1063/1.436216

Bhesaniya, K. and Baluja, S., Measurement and Correlation for Solubility of Some Pyrimidine Derivatives in Different Solvents. Journal of Applied Chemistry, 2014, article ID 450294 1-7, 2014. https://doi.org/10.1155/2014/450294

Bridger, G.L., and Chang, H.M., Separation of menthol from mint oils by a fractional distillation process. 1953 US PATENT. 2.662.052. 4 pages.

Budavari, S. (ed) The Merck Index: An Encyclopedia of Chemicals, Drugs, and Biologicals. 11th ed. New Jersey: Merck, 1989.

Galushko, A.A.; Sovová, H.; and Stateva R.P., Solubility of Menthol in pressurized carbon dioxide -Experimental data and thermodynamic modeling. Chemical Industry \& Chemical Engineering Quarterly, 12 (2), 152-158 (2006). https://doi. org/10.2298/CICEQ0603152G

Gatfield, I. L.; Hilmer, J.M.; Bornscheuer, U.; Schmidt, R. and Vorlová, S., Process for the preparation of L-menthol. US Patent US 6.706. 500 B2 (2004).

Gupta, A. K., Mishra, R., Singh, A. K., Srivastava, A., and Lal, R. K., Genetic variability and correlations of essential oil yield with agro-economic traits in Mentha species and identification of promising cultivars. Industrial Crops and Products, 95, 726-732 (2017). https://doi.org/10.1016/j.indcrop.2016.11.041

Hussain, A. I., Anwar, F., Nigam, P. S., Ashraf, M., and Gilani, A. H., Seasonal variation in content, chemical composition and antimicrobial and cytotoxic activities of essential oils from four Mentha species. Journal of the Science of Food and Agriculture, 90(11), 1827-1836 (2010). https://doi. org/10.1002/jsfa.4021

Li, H., Liu, J., Zhu, J., Zhao, L., Wang, H., and Zhang, Y., Correlation and comparison for solubility of pimelic acid in different solvents. Russian Journal of Physical Chemistry A, 86(2), 314-316 (2012). https://doi.org/10.1134/S0036024412020148
Mishra, D. S., \& Yalkowsky, S. H., Ideal solubility of a solid solute: effect of heat capacity assumptions, Pharm Res., 9(7) 958-959 (1992). https://doi. org/10.1023/A:1015873521067

Mukhopadhyay, M., and De, S. K., Fluid phase behavior of close molecular weight fine chemicals with supercritical carbon dioxide. Journal of Chemical and Engineering Data, 40(4), 909-913 (1995). https://doi.org/10.1021/je00020a038

Mullin, J.W., Chapter 3: Solutions and solubility. In: Crystallization. 4th. ed.. Butterworth-Heinemann. Oxford. United Kingdon. 2001. p. 92- 100.

Myerson, A.S., Chapter I: Solutions and Solution Properties. In Handbook of Industrial Crystallization. $2^{\text {nd }}$. Ed. Butterworth-Heinemann: Boston. MA. 2002. p. 11-13.

Nadeem, M. A., Dubey, R.; Singh, A., Pandey, R., and Bundelas, Processing and Quality Evaluation of Menthol Mint Oil. International Journal of Mathematics and Statistics Invention, 5(2), 68-70 (2017).

Noubigh, A., and Oueslati, M. H., Measurement and modeling of the solubility of vanillin constituent of olive mill wastewater in binary water+ ethanol solvents mixtures between $278.15 \mathrm{~K}$ and $308.15 \mathrm{~K}$, Aust. J. Basic Appl. Sci, 8, 396-403 (2014).

Nowak, R., Michler, M., Reiss, I., and Winkel, R., Menthol-containing solids composition. US 8.524.257 B2. 2013. 13 pages.

Nývlt, J.; Hostomský, J.; Giulietti, M., Cristalização. São Carlos: EdUFSCar/IPT, 2001. 160 p.,

Okuniewski, M., Paduszyński, K., and Domańska, U., Phase Diagrams in Representative Terpenoid Systems: Measurements and Calculations with Leading Thermodynamic Models. Industrial \& Engineering Chemistry Research, 56(34), 9753-9761 (2017). https://doi.org/10.1021/acs. iecr.7b02207

Sandler, S.I., Chapter 12. Section1. The solubility of a solid in a liquid. gas or supercritical fluid. In Chemical. Biochemical. and Engineering Thermodynamics. 5th. ed.. New York. John Wiley \& Sons. 2017. pp. 659-668.

Shi, Y. L., Qian, C., and Chen, X. Z., Solubility measurement and correlation of $(+)$-biotin intermediate lactone in different organic solvents from 287.15 to $323.75 \mathrm{~K}$. Journal of Chemical \& Engineering Data, 61(4), 1509-1516 (2016). https://doi.org/10.1021/acs.jced.5b00857

Singh, A. K., Raina, V. K., Naqvi, A. A., Patra, N. K., Kumar, B., Ram, P., and Khanuja, S. P. S., Essential oil composition and chemoarrays of menthol mint (Mentha arvensis L. f. piperascens Malinvaud ex. Holmes) cultivars. Flavour and fragrance Journal, 20(3), 302-305 92005). https:// doi.org/10.1002/ffj.1417 
Sovova, H., and Jez, J., Solubility of menthol in supercritical carbon dioxide. Journal of Chemical and Engineering Data, 39(4), 840-841 (1994). https://doi.org/10.1021/je00016a045

Tardugno, R., Pellati, F., Iseppi, R., Bondi, M., Bruzzesi, G., and Benvenuti, S. (2018). Phytochemical composition and in vitro screening of the antimicrobial activity of essential oils on oral pathogenic bacteria. Natural product research, 32(5), 544-551 (2018). https://doi.org/10. 1080/14786419.2017.1329730

Watts, S., Menthol and Cornmint Oil from China. Perfumer \& Flavorist; 22, 1-5 (1997). 